\title{
RELATIONSHIP BANKING WITHIN THE IRISH SME SECTOR AND ITS IMPLICATIONS
}

\author{
Sheila O' Donohoe \\ Waterford Institute of Technology, Ireland \\ Aoife Hanley \\ University of Kiel and Institute for World Economics (IfW), Germany \\ and \\ Clare Lyons \\ Deutsche Bank (London), United Kingdom
}

\begin{abstract}
Access to and the availability of finance for small firms has received considerable attention from policy makers. Somewhat more neglected is the concept of relationship banking, which this paper examines across two Irish regions, using the dimensions of proprietary information and multiple interactions between small firms and their bank(s). Findings from the survey suggest that SMEs maintain long and exclusive banking relationships and that bank overdraft interest margins vary significantly across firm size and duration of the banking relationship and with overdraft size. Smaller firms appear to pay more for their borrowings but it is unclear whether banks are discriminating excessively against them. This ambiguity is underpinned by the different composition of finance to smaller firms, who have smaller average overdrafts.
\end{abstract}

\section{INTRODUCTION}

More than 99 per cent of all business enterprises in the EU are categorised as small and medium-sized enterprises (SMEs). This is particularly true in Ireland, where they account for 97 per cent of all firms (Forfás, 2006). SMEs are generally characterised by the opacity of their operations and by a strong reliance on bank finance. Relationship intermediation is used by banks to ease resulting information asymmetry problems and the extant literature suggests that such intermediation can improve both the availability of bank finance and financing terms. Relationship banking involves the provision of financial services by an intermediary who 
O’ Donohoe, Hanley \& Lyons

a) invests in obtaining customer-specific information, often proprietary in nature, and $b$ ) evaluates the profitability of these investments through multiple interactions with the same customer over time and/or across products (Boot, 2000).

The present study contributes to the literature with an assessment of the presence and impact of relationship banking from an Irish SME perspective. The paper is structured as follows: the next section presents the theoretical motivations for and empirical evidence of relationship banking. This is followed by section three, which describes the sample and method used. The fourth section reports on the findings and the fifth provides a discussion of the results before, finally, the conclusion is presented.

\section{LITERATURE REVIEW}

Lenders have several tools at their disposal to help minimise the risks of dealing with potential borrowers (Coleman, 2000). One such tool is 'intermediation', which can be executed through two types of lending, namely relationship lending and transaction lending (Stein, 2002; Cole, Goldberg and White, 2004; Berger and Udell, 2006; Udell, 2008). Relationship lending is suited to more opaque enterprises and relies on the gathering by the lender of 'soft' information about the firm through a series of multiple interactions. This type of informal knowledge enables the lender to make better decisions on a credit application by the firm. In contrast, transaction lending relies more on 'hard' information as borrowers undergo a more formal structured process when applying for loans, including the provision of specific financial information and collateral, as these form the basis for underwriting the lenders' decisions (Elyasiani and Goldberg, 2004.)

Relationship banking has been measured by Petersen and Rajan (1994), Cole (1998), Degryse and Van Cayseele (2000), and Ennew and Binks (1996) through a series of variables, namely the length or duration of the relationship ('duration'), the breadth or scope of services sought ('scope'), the degree of concentration of borrowing ('concentration') and the extent of participation in the relationship ('participation'). A summary of the empirical evidence on relationship banking is presented in Table 1.

Duration reflects the degree of relationship intensity over time. In theory, the longer the relationship between a borrower and a lender, the greater the information flow between the two parties. This should lead to an increase in banks' willingness to provide funds, thus increasing the finance available to the firm (Berger and Udell, 2006). Empirical support in this regard is found by Petersen and Rajan (1994) and by Degryse and Van Cayseele (2000). However, a long relationship can generate a lock-in problem, with the incumbent bank having monopoly power over the borrower (Ongena and Smith, 2001).

The duration of Japanese and continental European bank relationships with small firms tend to be greater than their counterparts in the US, with the mean duration in Japanese companies being almost 30 years (Horiuchi, Packer and Fukuda, 1988) and in German companies 22 years (Elsas and Krahnen, 1998). The estimates for Sweden are for a mean of over 20 years (Sjögren, 1994) and a mean 
Relationship Banking Within the Irish SME Sector and Its Implications

TABLE I: EMPIRICAL EVIDENCE OF THE PRESENCE AND IMPACT OF RELATIONSHIP BANKING

\begin{tabular}{|c|c|c|c|c|c|}
\hline \multirow{2}{*}{$\begin{array}{l}\text { Author(s) } \\
\text { (Year) }\end{array}$} & \multirow{2}{*}{$\begin{array}{l}\text { Countryl } \\
\text { Context }\end{array}$} & \multicolumn{4}{|c|}{ Main Findings } \\
\hline & & $\begin{array}{l}\text { Duration } \\
\text { in Years }\end{array}$ & $\begin{array}{l}\text { Impact of } \\
\text { Duration }\end{array}$ & $\begin{array}{l}\text { Impact of } \\
\text { Scope }\end{array}$ & $\begin{array}{c}\text { Impact of } \\
\text { Concentration }\end{array}$ \\
\hline $\begin{array}{l}\text { Horiuchi et al. } \\
\text { (1988) }\end{array}$ & $\begin{array}{c}\text { Japan (1972- } \\
\text { 1983) }\end{array}$ & 30 & $\mathrm{n} / \mathrm{a}$ & $\mathrm{n} / \mathrm{a}$ & $\mathrm{n} / \mathrm{a}$ \\
\hline $\begin{array}{l}\text { Petersen and } \\
\text { Rajan } \\
\text { (1994) }\end{array}$ & US (1987) & 10.8 & $\begin{array}{l}\text { Positive impact } \\
\text { on credit } \\
\text { availability }\end{array}$ & $\begin{array}{l}\text { Choice of bank } \\
\text { for specific } \\
\text { services }\end{array}$ & $\begin{array}{l}\text { Concentrated } \\
\text { relationship } \\
\text { lowers bor- } \\
\text { rowing costs }\end{array}$ \\
\hline $\begin{array}{l}\text { Sjögren } \\
\text { (1994) }\end{array}$ & $\begin{array}{l}\text { Sweden } \\
(1997)\end{array}$ & $>20$ & $\mathrm{n} / \mathrm{a}$ & $n / a$ & $\mathrm{n} / \mathrm{a}$ \\
\hline $\begin{array}{l}\text { Petersen and } \\
\text { Rajan } \\
\text { (1995) }\end{array}$ & US (1987) & II & $\mathrm{n} / \mathrm{a}$ & $\mathrm{n} / \mathrm{a}$ & $\begin{array}{l}\text { Concentrated } \\
\text { relationship } \\
\text { lowers bor- } \\
\text { rowing costs } \\
\text { and reduces } \\
\text { liquidity } \\
\text { constraints }\end{array}$ \\
\hline $\begin{array}{l}\text { Berger and } \\
\text { Udell (1995) }\end{array}$ & $\begin{array}{l}\text { US } \\
\qquad(1988-1989)\end{array}$ & 11.39 & $\begin{array}{l}\text { Positive impact } \\
\text { on borrowing } \\
\text { costs }\end{array}$ & $\mathrm{n} / \mathrm{a}$ & $\mathrm{n} / \mathrm{a}$ \\
\hline $\begin{array}{l}\text { Ennew and } \\
\text { Binks (1996) }\end{array}$ & UK (1992) & $n / a$ & $\mathrm{n} / \mathrm{a}$ & $\mathrm{n} / \mathrm{a}$ & $\begin{array}{l}\text { Participation in } \\
\text { the banking } \\
\text { relationship } \\
\text { has a positive } \\
\text { impact on } \\
\text { growing firms }\end{array}$ \\
\hline $\begin{array}{l}\text { Blackwell and } \\
\text { Winters } \\
\text { (1997) }\end{array}$ & US (1988) & 9.01 & $\begin{array}{l}\text { Positive impact } \\
\text { on borrowing } \\
\text { costs }\end{array}$ & $\mathrm{n} / \mathrm{a}$ & $\begin{array}{l}\text { Concentrated } \\
\text { relationship } \\
\text { lowers bor- } \\
\text { rowing costs }\end{array}$ \\
\hline Cole (1998) & US (1993) & 7.03 & $\mathrm{n} / \mathrm{a}$ & $\mathrm{n} / \mathrm{a}$ & $\begin{array}{l}\text { Concentrated } \\
\text { relationship } \\
\text { enhances } \\
\text { credit availability }\end{array}$ \\
\hline $\begin{array}{l}\text { Ennew and } \\
\text { Binks (1998) }\end{array}$ & UK & $n / a$ & $\mathrm{n} / \mathrm{a}$ & $\mathrm{n} / \mathrm{a}$ & $\begin{array}{l}\text { Participative } \\
\text { firms incur } \\
\text { lower interest } \\
\text { rates v. non- } \\
\text { participative } \\
\text { firms }\end{array}$ \\
\hline $\begin{array}{l}\text { Angelini et al. } \\
\text { (1998) }\end{array}$ & $\begin{array}{l}\text { Italy } \\
\text { (1995) }\end{array}$ & 14 & $\mathrm{n} / \mathrm{a}$ & $\mathrm{n} / \mathrm{a}$ & $\begin{array}{l}\text { Concentrated } \\
\text { relationship } \\
\text { enhances } \\
\text { credit availability }\end{array}$ \\
\hline
\end{tabular}


O' Donohoe, Hanley \& Lyons

TABLE I: CONTINUED

\begin{tabular}{|c|c|c|c|c|c|}
\hline \multirow{2}{*}{$\begin{array}{l}\text { Author(s) } \\
\text { (Year) }\end{array}$} & \multirow{2}{*}{$\begin{array}{l}\text { Countryl } \\
\text { Context }\end{array}$} & \multicolumn{4}{|c|}{ Main Findings } \\
\hline & & $\begin{array}{l}\text { Duration } \\
\text { in Years }\end{array}$ & $\begin{array}{l}\text { Impact of } \\
\text { Duration }\end{array}$ & $\begin{array}{l}\text { Impact of } \\
\text { Scope }\end{array}$ & $\begin{array}{c}\text { Impact of } \\
\text { Concentration }\end{array}$ \\
\hline $\begin{array}{l}\text { Harhoff and } \\
\text { Körting } \\
\text { (1998) }\end{array}$ & $\begin{array}{r}\text { Germany } \\
(1998)\end{array}$ & \pm 12 & $\mathrm{n} / \mathrm{a}$ & $\mathrm{n} / \mathrm{a}$ & $\begin{array}{l}\text { Concentrated } \\
\text { relationship } \\
\text { lowers bor- } \\
\text { rowing costs } \\
\text { and enhances } \\
\text { credit availability }\end{array}$ \\
\hline $\begin{array}{l}\text { Elsas and } \\
\text { Krahnen } \\
(1998)\end{array}$ & $\begin{array}{l}\text { Germany } \\
\quad(1992-1996)\end{array}$ & 22.2 & $\begin{array}{l}\text { No impact on } \\
\text { borrowing } \\
\text { costs }\end{array}$ & $\mathrm{n} / \mathrm{a}$ & $\mathrm{n} / \mathrm{a}$ \\
\hline $\begin{array}{l}\text { Ongena and } \\
\text { Smith } \\
(2000)\end{array}$ & $\begin{array}{c}\text { Cross-country } \\
\text { data (1996) }\end{array}$ & $\mathrm{n} / \mathrm{a}$ & $\mathrm{n} / \mathrm{a}$ & $\begin{array}{l}\text { Scope has a } \\
\text { positive } \\
\text { impact } \\
\text { on lending }\end{array}$ & $\begin{array}{l}\text { Significant } \\
\quad \text { variation in } \\
\text { number of } \\
\text { relationships } \\
\text { across } \\
\text { countries }\end{array}$ \\
\hline $\begin{array}{l}\text { Degryse and } \\
\text { Van Cayseele } \\
(2000)\end{array}$ & Belgium (I997) & 7.82 & $\begin{array}{l}\text { Negative impact } \\
\text { on borrowing } \\
\text { costs }\end{array}$ & $\begin{array}{l}\text { Scope has a } \\
\text { positive } \\
\text { impact on } \\
\text { cost of credit }\end{array}$ & $\mathrm{n} / \mathrm{a}$ \\
\hline $\begin{array}{l}\text { Ongena and } \\
\text { Smith } \\
(2001)\end{array}$ & $\begin{array}{l}\text { Norway } \\
\quad(1979-1995)\end{array}$ & $\begin{array}{l}(15.8- \\
18.1)\end{array}$ & $\begin{array}{l}\text { Firms likely } \\
\text { to end the } \\
\text { relationship } \\
\text { as it matures }\end{array}$ & $\mathrm{n} / \mathrm{a}$ & $\mathrm{n} / \mathrm{a}$ \\
\hline $\begin{array}{l}\text { Lehmann and } \\
\text { Neuberger } \\
\text { (2001) }\end{array}$ & $\begin{array}{r}\text { Germany } \\
(1997)\end{array}$ & $\mathrm{n} / \mathrm{a}$ & $\begin{array}{l}\text { Negative impact } \\
\text { on borrowing } \\
\text { costs }\end{array}$ & $\mathrm{n} / \mathrm{a}$ & $\mathrm{n} / \mathrm{a}$ \\
\hline $\begin{array}{l}\text { Bodenhorn } \\
(2003)\end{array}$ & $\begin{array}{c}\text { US (1844- } \\
1860)\end{array}$ & 4.2 & $\begin{array}{l}\text { Positive impact } \\
\text { on borrowing } \\
\text { costs }\end{array}$ & $\mathrm{n} / \mathrm{a}$ & $\mathrm{n} / \mathrm{a}$ \\
\hline Elsas (2005) & $\begin{array}{l}\text { Germany } \\
\quad(1992-1996)\end{array}$ & 18 & $\mathrm{n} / \mathrm{a}$ & $\mathrm{n} / \mathrm{a}$ & $\begin{array}{l}\text { Concentrated } \\
\text { relationship } \\
\text { enhances } \\
\text { credit availability }\end{array}$ \\
\hline $\begin{array}{l}\text { Hanley et al. } \\
(2006)\end{array}$ & $\begin{array}{r}\text { UK(1996 } \\
-2002)\end{array}$ & 15 & $\mathrm{n} / \mathrm{a}$ & $\mathrm{n} / \mathrm{a}$ & $\mathrm{n} / \mathrm{a}$ \\
\hline $\begin{array}{l}\text { Hernandez- } \\
\text { Canavas and } \\
\text { Martinez- } \\
\text { Solano } \\
(2006)\end{array}$ & $\begin{array}{l}\text { Spain (1999- } \\
2000)\end{array}$ & 16.8 & $\begin{array}{l}\text { Negative impact } \\
\text { on borrowing } \\
\text { costs }\end{array}$ & $\mathrm{n} / \mathrm{a}$ & $\begin{array}{l}\text { Concentrated } \\
\text { relationship } \\
\text { lowers } \\
\text { borrowing } \\
\text { costs }\end{array}$ \\
\hline $\begin{array}{l}\text { Peltoniemi } \\
\text { (2007) }\end{array}$ & $\begin{array}{l}\text { Finland } \\
(2002)\end{array}$ & 9 & $\begin{array}{l}\text { Positive impact } \\
\text { on borrowing } \\
\text { costs }\end{array}$ & $\mathrm{n} / \mathrm{a}$ & $\mathrm{n} / \mathrm{a}$ \\
\hline
\end{tabular}


of 14 years in Italy (Angelini, Di Salvo and Ferri, 1998). In contrast, most of the US estimates of duration are for between 7 and 11 years on average (Petersen and Rajan, 1995; Blackwell and Winters, 1997; Cole, 1998), and the mean is 9 years in Finland (Peltoniemi, 2007).

In addition to interactions over time, relationships can be built through interaction over multiple products (scope), which have information generation implications and may affect contract terms (Degryse and Van Cayseele, 2000). Ongena and Smith (2000) find a positive relationship between scope and the number of lenders in a business-bank relationship, which suggests that firms choose a particular bank for a specific financial service.

In a similar vein, the number of bank relationships can serve as an indicator of the presence of relationship lending and is based on the premise that maintaining an exclusive bank relationship promotes the development of close ties between bank and borrower (Elsas, 2005). Here the commonly used proxy in the literature for the number of lenders is the concentration of borrowing. Ongena and Smith (2000) note that in the studies conducted in Sweden and Norway, a maximum number of six bank relationships were found, while the majority of firms in Italy, Portugal and Spain maintain at least six bank relationships. In a study of the banking relationships across 20 European countries, Ongena and Smith (2000) also found that Italian firms, on average, had 15.2 relationships and Norwegian firms had the lowest average, 2.3. In their study of Italian SMEs, Angelini et al. (1998) found the average number of lenders to be 2.4. Compared to the Italian results, Harhoff and Körting (1998) found that German SMEs maintain relatively more exclusive borrowing relationships, where German firms borrow on average from 1.81 banks.

Degryse and Van Cayseele (2000) use a variable, main, to measure the strength of the financial relationship and they use the scope of the relationship as the criteria to decide whether the relationship qualifies as that of a main bank. A main bank is one which provides 80 per cent or more of a firm's products. They posit that a main bank relationship should improve the accuracy of the bank's information and hence reduce the monitoring costs.

The final measure of relationship banking is a willingness to participate in the relationship, a variable drawn from the interaction-based literature. Ennew and Binks (1996) developed metrics to gauge the level of participation in UK banking relationships and while participation is evidently a multi-faceted concept, its essential elements were held to be a willingness to communicate and a willingness to share information.

Berger and Udell (1995) note that a test of whether banking relationships affect loan rates is in fact a joint test of whether a) prospective lenders gather valuable information from relationships, b) they use this information in pricing loans and c) this information is reflected in the observed loan rates (Cole, 1998).

The duration of the banking relationship is shown to have a significantly positive impact on loan rates for US SMEs by Berger and Udell (1995), Blackwell and Winters (1997) and Bodenhorn (2003), as well as in Finland (Peltoniemi, 2007), Germany (Lehmann and Neuberger, 2001) and Spain (Hernandez-Canavas and Martinez-Solano, 2006). While these studies are contrasted with the evidence for 
O’ Donohoe, Hanley \& Lyons

Belgian firms by Degryse and Van Cayseele (2000), the weight of international evidence supports the 'hold up problem' hypothesis. According to this hypothesis, lenders attract borrowers with initially cheap finance. Once the borrower's risk type becomes known, this private information is retained by the lender. Subsequent rounds of finance are priced above the lender's actuarial rate of return because the lender is confident that the borrower will receive less competitive rates with other lenders who do not know the borrower's revealed risk type. Furthermore, any effort by the borrower to withdraw their custom and borrow elsewhere will be construed by other lenders negatively: they will conjecture that the borrower is a 'lemon', i.e. poses a high default risk and has been priced out or denied finance by the initial lender. This evidence questions the merits of long banking relationships between small firms and their banks, such stable banking relationships being a feature of borrowing in bank-dominated countries such as Germany. Rather surprisingly, there is limited evidence to suggest that risk-cost reductions are passed along to the firm over the course of these relationships. Instead it suggests that the value of previously accumulated private information can increase or decrease over some time as the firm establishes a track record (Diamond, 1991) or that the marginal value of additional information may increase or decrease over time (Elsas, 2005).

The existence of strong support for the single/main bank hypothesis is found where an exclusive banking relationship exerts a positive impact on loan rates to small firms. In the US, Petersen and Rajan (1994) and Blackwell and Winters (1997) have documented evidence for exclusive bank relationships. Further evidence exists for Belgium in a study by Degryse and Van Cayseele (2000) and for Spanish SMEs in a study by Hernandez-Canavas and Martinez-Solano (2006). Ennew and Binks $(1996,1998)$ show that UK firms who participate in banking relationships incur lower lending costs compared to non-participative firms, having controlled for other financing variables, firm size and the degree of business risk. ${ }^{1}$

In summary, there is a considerable volume of work that examines the presence of relationship banking in the US, continental Europe, Japan and the UK. While significant evidence exists to support the prevalence of lender-business relationships, few studies document the implications of relationship banking on the availability and cost of borrowing for the small firm sector. To our knowledge, no study of this phenomenon has been carried out for Ireland as a unique setting. In particular, the study examines the extent to which the Irish context differs from the continental banking system and, hence, the implications of such findings for lender-business relationships.

\section{DATA AND METHOD}

The main objective of the present study is to investigate the presence and significance of bank-business relationships within the Irish business banking market. The study focuses on two regions in Ireland: Dublin and the south-east. The former is considered an urban region, in contrast with the south-east, which is predominantly rural. This facilitates a comparison of rural and urban financial 
Relationship Banking Within the Irish SME Sector and Its Implications

TABLE 2: ORIGINAL SAMPLE AND RESPONDENTS

\begin{tabular}{|c|c|c|c|c|}
\hline \multirow{2}{*}{$\begin{array}{l}\text { Firm Location } \\
\text { Dun \& Bradstreet } \\
\text { Register }\end{array}$} & \multicolumn{2}{|c|}{ Sampled Firms } & \multicolumn{2}{|c|}{ Respondent Firms } \\
\hline & Number & Percentage & Number & Percentage \\
\hline South-east & 200 & 33.4 & 56 & 34.4 \\
\hline Dublin north & 110 & 18.4 & 29 & 17.8 \\
\hline Dublin south & 270 & 45.0 & 75 & 46.0 \\
\hline Co. Dublin & 20 & 3.2 & 3 & 1.8 \\
\hline Total & 600 & 100 & 163 & 100 \\
\hline
\end{tabular}

intermediation given Petersen and Rajan's findings (1995) that credit constraints are less severe in rural areas as a result of greater information availability about small businesses and their managers.

A sample size of 600 firms was used in the present study, representing approximately 1 per cent of the population. Stratification was employed in order to ensure the sample was representative; the final sample comprising 400 SMEs from Dublin and 200 SMEs from the south-east. Additionally, the sample was stratified to reflect the clusters of firms within the south-east, broken down by county, and Dublin, broken down by area code. Both of the more focused breakdowns followed the proportions set by Dun and Bradstreet (2001). With the two levels of clustering, it was necessary to sample at two different stages. The sample within the clusters was drawn using systematic sampling, where every $\mathrm{n}^{\text {th }}$ firm was selected depending on the size of the cluster. Table 2 demonstrates the sample breakdown within the two regions as well as the breakdown of the respondents to the survey.

A tailor-made questionnaire was administered through the postal system in early 2005 to the owner-managers of the firms sampled. This achieved a 27 per cent response rate. A series of analytical tests for non-response bias was carried out, similar to those outlined by Armstrong and Overton (1977), and no significant differences emerged.

The purpose of the study was to seek factual data, as well as the desire to gauge the opinion of respondent SMEs. With this in mind, quantitative data was sought and this required a survey that facilitated wide distribution.

The questionnaire employed was designed based on both the review of the literature and methodological approaches adopted within the relationship intermediation literature. To ensure it was easy to follow the survey was split into two sections, titled 'Relationship with Banks' and 'Bank Financing and Firm Characteristics'.

Appendix 1 contains the instrument used. A pilot study was conducted with disproportionate stratified systematic sampling employed to identify 50 firms split evenly across Dublin and the south-east regions. This was carried out in such a manner as to ensure an adequate number of firms responded from both regions. The results indicated that only a few minor changes were required that were incorporated into the final questionnaire, which was then made ready for distribution. 
O’ Donohoe, Hanley \& Lyons

\section{RESULTS}

\section{Profile of the Respondent Firms}

The sample was comprised of 163 SMEs, 34 per cent of which from the south-east and 66 per cent from the greater Dublin area; of which 23 per cent were micro firms (those with fewer than ten employees), 61 per cent small and 16 per cent medium-sized enterprises, with more micro firms in Dublin and more mediumsized firms in the south-east. Respondent businesses have a mean age of 21 years and mean size of 32 employees. Firms in the south-east appear, on average, to be older and larger than their Dublin counterparts and have a greater proportion of manufacturing firms. The split between the manufacturing and services sectors is 30/70, with the three main sectors of business services, wholesale and construction accounting for up to 57 per cent of respondent firms. The average growth rate of these firms over the past three years is approximately 17 per cent, with businesses in the south-east found to have experienced faster growth rates than their Dublin counterparts.

Evidence is shown of high levels of interaction with the local branch, account/relationship manager and branch manager levels. This holds for both regions, with firms in the south-east demonstrating slightly higher levels of interaction.

With 93 per cent of firms adopting at least one alternative mode of banking, it is not surprising that this resulted in fewer branch visits. Reasons cited for not using alternative modes included a lack of awareness of any advantages from doing so and the opinion that the online and tele-banking services offered by their bank were poor. One firm stated that, 'internet does not give the personal touch'. In addition to not being aware of the benefits, one firm that uses its bank's online services comments that, 'a constant source of annoyance with all our banks is having to pay for internet banking. I cannot understand why we have to pay when we are reducing the bank's costs'.

When asked about the type of information banks sought when first opening a bank account or when applying for the first loan or further additional loans, respondents cited that banks place a strong emphasis on the owner's investment type and on their detailed business plan and projected cash flows at the initial stage of opening an account. Upon application for the first loan, a lender's main focus appears to be on firms' projected cash flows, the detailed business plan and sales projections. Alternatively, the financial statements (profit and loss and balance sheet) are deemed more useful when additional loans are sought and over the course of the ongoing banking relationship.

Given the considerable tendency to request information at the time of the first loan, it would appear that banks gather data for loan decision making and thus relationship banking could provide an important mechanism for gathering the data necessary for reducing information asymmetries. When asked about their perception as to why banks gathered information, the majority of respondents view it positively, with 79 per cent seeing it as part of the bank's ongoing monitoring process and 52 per cent as a mechanism of enhancing the bank's trust in the 
Relationship Banking Within the Irish SME Sector and Its Implications

firm, while just 21 per cent see it as a way for banks to gain more power over the business.

\section{Borrowing Patterns}

Up to 21 per cent of respondents have had no bank borrowings over the last three years and some of the reasons cited for this are: ${ }^{2}$

(a) 'Banks are a bad source of financing/loan products; other sources of finance are better (e.g. equity, EU schemes)'

(b) 'Banks do not provide loan or overdraft or working capital to SME software companies - the only way to finance is to sell equity'

(c) 'Our business is constantly focused on retaining a positive cash flow so that we don't have to pay the bank for excessive charges on overdraft facilities'

(d) 'We retain relatively high amounts of cash in the company (relative to turnover), to ensure that we can cash flow almost any scale of project, even in the event of a substantial delay in receipt of payments from customer. Therefore, we are effectively our own bank; this situation has arisen because the bank (and others we have approached) are not prepared to offer an unsecured overdraft facility...'

Table 3 indicates that approximately half of the firms responding did not get a bank loan to start their business. Significantly more firms in the south-east region sought their first loan at the same time as opening the business account.

Firms appear to use a variety of loan products, as demonstrated in Table 4, with bank overdrafts representing both the most popular instrument and the financial product most valued by businesses. The other most widely used product is the credit card, whilst invoice discounting is rated very highly by those who use it.

Further analysis of the costs of the products reveals how hire purchase (HP) and leasing are the most expensive sources of finance, while bank overdrafts manifest the greatest variation in cost. There is considerable variation in terms of loan volume, where up to 90 per cent of loans for greater than five years are in excess of $€ 100,000$. Conversely, 54 per cent of bank overdrafts, the most popular type of

TABLE 3: STAGE AT WHICH FIRST LOAN WAS SOUGHT

\begin{tabular}{lcc}
\hline & $\begin{array}{c}\text { South-East } \\
\%\end{array}$ & $\begin{array}{c}\text { Dublin } \\
\%\end{array}$ \\
\hline Never & 5.5 & 19.4 \\
With account opening & 43.6 & 28.2 \\
Within 6 months & 3.6 & 4.9 \\
Within I2 months & 16.4 & 5.8 \\
At a later stage & 30.9 & 41.7 \\
Total & 100 & 100 \\
\hline
\end{tabular}


O’ Donohoe, Hanley \& Lyons

TABLE 4: LOAN IMPORTANCE

\begin{tabular}{lccccccc}
\hline & $\begin{array}{c}\text { No. of } \\
\text { Firms }\end{array}$ & $\begin{array}{c}\text { Average } \\
\text { Rating } \\
\text { Min=1 \& } \\
\text { Max=5 }\end{array}$ & $\begin{array}{c}\text { Not } \\
\text { Impor- } \\
\text { tant } \\
\%\end{array}$ & $\begin{array}{c}\text { Of Little } \\
\text { Impor- } \\
\text { tance } \\
\%\end{array}$ & $\begin{array}{c}\text { Moderately } \\
\text { Impor- } \\
\text { tant } \\
\%\end{array}$ & $\begin{array}{c}\text { Impor- } \\
\text { tant }\end{array}$ & $\begin{array}{c}\text { Very } \\
\text { impor- } \\
\text { tant } \\
\%\end{array}$ \\
\hline Bank loan < 5years & 40 & 2.93 & 32.5 & 5.0 & 20.0 & 22.5 & 20.0 \\
Bank loan > 5 years & 47 & 3.23 & 25.5 & 4.3 & 12.8 & 36.2 & 21.2 \\
Working capital & 35 & 3.26 & 28.6 & 2.9 & 14.3 & 22.9 & 31.3 \\
Overdraft & 84 & 3.87 & 7.1 & 6.0 & 14.3 & 38.1 & 34.5 \\
Commercial mortgage & 32 & 3.16 & 28.1 & 3.1 & 15.6 & 31.2 & 22.0 \\
Hire purchase & 40 & 3.00 & 25.0 & 5.0 & 25.0 & 35.0 & 10.0 \\
Invoice discounting & 35 & 3.00 & 45.7 & 2.9 & 2.9 & 11.4 & 37.1 \\
Supplier finance & 22 & 2.91 & 68.2 & 0.0 & 9.1 & 13.6 & 9.1 \\
Credit cards & 58 & 1.95 & 10.3 & 17.2 & 20.7 & 32.8 & 19.0 \\
Other loans & 3 & 3.3 & 0.0 & 0.0 & 0.0 & 33.3 & 66.7 \\
\hline
\end{tabular}

finance, amount to less than $€ 50,000$, with 56 per cent exceeding that amount. Unsurprisingly, firm size is positively related to loan size.

Up to 66 per cent of firms believe that they would need finance for future expansion, with a greater number of Dublin respondents (78 per cent) reporting this to be the case vis-à-vis those in the south-east (41 per cent). This result is not surprising given the composition of the firms in each region. It is surprising that more small and medium firms (over 70 per cent of each) cited the need for additional finance, in contrast to the micro firms (55 per cent). Of those seeking funding in the near future, up to 92 per cent believe it is available, suggesting no major difficulties in sourcing finance. When asked about what financing terms they would be prepared to endure in order to gain finance, the results suggest that firms in the south-east are willing to undertake the most severe deterioration in conditions (collateral required and interest rate charged) in contrast to their Dublin counterparts. Measures of liquidity constraint demonstrate that there is a greater tendency for this to exist within the south-east sample than in Dublin.

In summary, approximately 21 per cent of SMEs in this sample had no bank borrowings over the past three years. There are various reasons for this, including the lack of a borrowing requirement, company policy on borrowing or access to alternative sources of finance. Of those who do borrow, most do so at a later stage in their relationship with the bank. The bank overdraft facility is the most popular source of loan finance. This financial product also accounts for the greatest volume of credit from lenders. Firms use a variety of loan instruments, especially to fund working capital. The cost of finance varies considerably across the different sources used, with HP and leasing depicted as the most expensive sources. Access to finance does not appear to be a problem for respondents and most do not appear to have liquidity constraints. Up to 42 per cent of firms agree that relationship banking has had a positive impact on the firm's development, with 39 per cent remaining neutral on the matter and approximately 21 per cent disagreeing with this statement. 
Relationship Banking Within the Irish SME Sector and Its Implications

\section{Relationship Characteristics}

The findings suggest that SMEs across both regions maintain relatively exclusive banking relationships as up to 73 per cent have been with their current bank for more than 10 years. The average duration of bank-SME relations for the southeast sample is 19.4 years, compared to 17.9 years in Dublin. Table 5 suggests that firms in the south-east are more likely to maintain longer relationships, whereas in Dublin relationships are more fragmented over the duration. This result is not surprising as south-east firms are older on average, but the difference is not statistically significant.

The average number of products and/or services procured by firms in this study from all of their banks is 2.6. No significant difference appears between the average number of products procured by firms in Dublin (2.57) versus the southeast (2.64). Similar findings are revealed when the focus is placed on services and products sourced at a firm's main bank, with an average of 2.44. Moreover, firms in the south-east appear to source, on average, 2.5 products at their main bank compared to 2.41 in Dublin. However, it appears that the larger the firm, the greater the number of products sought.

Respondents were asked to identify the financial institutions they use as either a main bank (a bank with whom they conduct 80 per cent or more of their financial transactions) or non-main bank (dealings that account for less than 80 per cent). The average number of banks servicing the respondent SMEs is 2.15, suggesting that firms deal with more than one bank. The consensus in the literature is that SMEs tend to have fewer bank relationships than large enterprises. This also proves to be the case within this sample.

Approximately 32 per cent of the respondent firms deal with two banks, which is similar to the 35 per cent found by Ongena and Smith (2000) in their comprehensive analysis of the number of bank relationships across firms and countries. Hence, the majority of firms in both studies engage with one or two banks. Ongena and Smith (2000) found that 58.7 per cent of firms deal with one or two banks, compared to 71 per cent in this analysis. They assert that the variation in the number of banking relationships held by firms is due to the nature of the banking system and judicial systems, i.e. firms in countries with relatively stable

TABLE 5: DURATION OF THE BANKING RELATIONSHIP

\begin{tabular}{lccc}
\hline & $\begin{array}{c}\text { South-East } \\
\%\end{array}$ & $\begin{array}{c}\text { Dublin } \\
\%\end{array}$ & $\begin{array}{c}\text { Total } \\
\%\end{array}$ \\
\hline I-5 years & 8.9 & 13.1 & 11.7 \\
6-10 years & 14.3 & 15.9 & 15.3 \\
II-20 years & 37.5 & 27.1 & 30.7 \\
2I-30 years & 7.1 & 18.7 & 14.7 \\
More than 30 years & 32.2 & 25.2 & 27.6 \\
Total & 100 & 100 & 100 \\
\hline
\end{tabular}

Note: $\chi^{2}$ value $=5.85, \mathrm{p}$-value $=0.21$ 
and unconcentrated banking systems have more banking relationships than those in strong judicial systems with strong creditor protection.

Firms in the south-east, on average, appear to engage with more banks (2.36) compared with Dublin firms (2.04). While there is only a marginal difference between the two findings, and ultimately the mean number of banks for both regions is two, the difference is statistically significant at the 1 per cent level. The average number of banks increases with each size class: micro (1.58), small (2.18) and medium (2.85). Hence, the larger the firm, the more banks it tends to use, a finding consistent with Ongena and Smith's findings (2000) for Irish firms and their wider sample-frame for firms from 20 countries. Harhoff and Körting (1998) also find that the mean and median number of bank relationships increase with firm size for German firms. They indicate two reasons for this, with the simplest explanation relating to the fixed costs for maintaining a borrowing relationship.

The number of lenders providing finance is used to gauge the level of concentration. Additionally, the percentage of the business borrowings held with the principal lender and whether the principal lender is the firm's main bank are explored for a greater understanding of the extent of debt concentration. Up to 52 per cent borrow from just one bank, while a further 17 per cent borrow from two banks, with a mean of 1.46 and mode of 1 , suggesting that banking is relatively concentrated in this sample. Across the regions, respondents in the south-east appear to borrow more and do so from more than one bank: up to 75 per cent of Dublin firms borrow from just one bank compared with 62 per cent in the southeast. As with Elsas (2005), the number of lenders appears to increase significantly with firm size. Further tests of the level of concentration reveal that for 81 per cent of firms their main bank is also their principal lender.

Firms' participation in the banking relationship is assessed by their willingness to provide financial information on a regular basis to their bank, by having regular meetings with them and by discussing any financing issues they may have with their bank. While participation is evidently a multi-faceted concept, its essential elements were held to be a willingness to communicate and a willingness to share information (Ennew and Binks, 1996).

From Table 6, it appears that the majority of businesses surveyed participate with the financial institutions to the extent indicated. Over 80 per cent of respondents agreed with the statement 'that it is important to discuss excess borrowings with the banks', while 57 per cent of respondents agreed that 'it is important to provide banks with regular and timely information', with only 11 per cent stating that they would 'prefer to avoid contact with the bank or bank manager'. A discriminant function was applied with participation as the discriminant value and the factors 'provide information', 'avoid contact' and 'discuss excess borrowings' as the predictor variables, with the value of this function significantly different for participating and non-participating businesses at the 1 per cent level.

In summary, SMEs in both regions appear to maintain relatively exclusive banking relationships, with relatively high levels of interaction between the parties, despite most using internet and/or telephone banking (up to 57 per cent visit their bank on a daily or weekly basis). Furthermore, there is evidence of SMEs sourcing multiple products from their main bank, in particular, and concentrating 
TABLE 6: LEVEL OF PARTICIPATIVE BANKING

\begin{tabular}{|c|c|c|c|c|}
\hline Statement & $\begin{array}{c}\text { Average } \\
\text { Rating } \\
\text { Min = I \& Max =5 }\end{array}$ & $\begin{array}{c}\text { Disagree } \\
\%\end{array}$ & $\begin{array}{c}\text { Neutral } \\
\%\end{array}$ & $\begin{array}{c}\text { Agree } \\
\%\end{array}$ \\
\hline $\begin{array}{l}\text { It is important to discuss } \\
\text { excess borrowings with } \\
\text { the bank manager }\end{array}$ & 4.06 & 3.16 & 12.03 & 84.81 \\
\hline $\begin{array}{l}\text { It is important to provide } \\
\text { the bank with regular and } \\
\text { timely information }\end{array}$ & 3.48 & 16.25 & 26.88 & 56.88 \\
\hline $\begin{array}{l}\text { You prefer to avoid any } \\
\text { contact with the bank } \\
\text { or bank manager } \\
N=160,160,157 \text { respectively }\end{array}$ & 2.20 & 66.24 & 22.93 & 10.83 \\
\hline
\end{tabular}

the current account with the main bank also. There is also strong evidence to support debt concentration, with a mean number of lenders of 1.46 and a mode of 1 . While there is a tendency for the bank to gather data from firms at the application stage (for an initial loan), there is additional evidence to conclude that the bank updates its firm-specific information over the duration of its dealings with the firm.

While there is evidence that the bank requires a lot of information about the firm's management at the outset of the relationship, the number of firms asked to provide such data falls as the relationship matures. This would imply that banks no longer gather information about the firms' management on a formal basis. Rather they gain this information informally. Information is deemed to play an important role in the establishment and maintenance of the banking relationship. SMEs perceive information gathering by the bank to be an important part of the monitoring mechanism, but it is also considered a process enabling the bank to sell more products/services to business customers.

Firms appear willing to participate in the lender-business relationship and 79 per cent agree that 'banks are vital in the life of small businesses'. Finally, SMEs' perception of interacting with their bank reveals that the majority agree that meeting with bank personnel is beneficial and that they would seek the advice of the bank at a time of financial distress.

\section{Impact of the Banking Relationship on Lending Terms}

Following Berger and Udell (1995), the only interest rate investigated in the present study is the overdraft rate; this is due to the fact that it is deemed a relationshipdriven loan and not a transaction-driven loan. Tests are conducted for the impact of a number of variables on overdraft interest rates and these include the length or duration of the banking relationship, bank concentration, firm characteristics, overdraft size and finally the role across the two participative clusters. 
O’ Donohoe, Hanley \& Lyons

TABLE 7: IMPACT OF DURATION CHARACTERISTIC ACROSS THE OVERDRAFT INTEREST RATE

\begin{tabular}{|c|c|c|c|c|c|c|}
\hline $\begin{array}{l}\text { Overdraft Interest } \\
\text { Rate }\end{array}$ & $\begin{array}{c}\text { Mean } \\
\text { Duration } \\
\%\end{array}$ & $\begin{array}{c}\text { Duration } \\
\text { I-5 yrs } \\
\%\end{array}$ & $\begin{array}{c}\text { Duration } \\
6-10 \text { yrs } \\
\%\end{array}$ & $\begin{array}{c}\text { Duration } \\
\text { I |-20 yrs } \\
\%\end{array}$ & $\begin{array}{c}\text { Duration } \\
2 \text { I-30 yrs } \\
\%\end{array}$ & $\begin{array}{c}\text { Duration } \\
>30 \text { yrs } \\
\%\end{array}$ \\
\hline 4-5.9\% & 27 & 0 & 14.3 & 16 & 50 & 45.8 \\
\hline $6-7.9 \%$ & 14 & 44.4 & 35.7 & 28 & 8.3 & 12.5 \\
\hline 8-9.9\% & 17 & 44.4 & 28.6 & 40 & 4.7 & 41.7 \\
\hline | $0-|| .9 \%$ & 12 & II.I & 21.4 & 16 & 0 & 0 \\
\hline $12-13.9 \%$ & - & 0 & 0 & 0 & 0 & 0 \\
\hline
\end{tabular}

In Table 7 interest rates are shown to vary with the duration of the banking relationship. The shorter the duration the greater the likelihood of paying higher rates, and the difference is statistically significant at the 5 per cent level $\left(\chi^{2}=\right.$ 22.036, $d f=12, p=0.024)$. This result is consistent with the US evidence of Berger and Udell (1995) and Blackwell and Winters (1997), the Italian evidence of Angelini et al. (1998) and the Finnish evidence of Peltoniemi (2007), and contrasts with the Belgian study of Degryse and Van Cayseele (2000) and the Spanish study of Hernandez-Canavas and Martinez-Solano (2006).

In addition, it would appear from Table 8 that firms in multi-bank relationships pay higher rates compared to those with an exclusive relationship. This result is consistent with Petersen and Rajan (1994), who tentatively show that a single banking relationship lowers borrowing costs. Similar to their findings, the difference is not statistically significant. Accordingly, there is no major evidence to suggest that borrowing from the main bank will result in lower interest charges. No significant differences arise between interest rates charged by lender type (principal or ancillary lender). Similarly, no significant difference arises in the price of finance when the proportion borrowed from the main lender is less than or greater than 80 per cent. In fact, there is some weak evidence of lower rates when the principal lender is not the main bank and when the proportion borrowed from the main bank is less than 80 per cent. If anything, our evidence leans in the direction of the Hanley, Ennew and Binks study (2006), which found exclusive business-bank relationships to be counter-productive for small firms, where lenders with higher concentrations of SME finance charged higher rates.

An examination of the difference in interest rates and firm size reveals a significant inverse relationship, as medium-sized firms incur lower rates in comparison to micro enterprises. The difference is statistically significant at the 10 per cent level $\left(\chi^{2}=11.225, d f=6, p=0.102\right)$ and is tabulated in Table 9 and in Figure 1. Micro enterprises appear to pay higher interest on their overdrafts than either their small or medium-sized counterparts. This finding is consistent with the results depicted in Table 7 , where duration has a negative but significant effect on interest charges.

In the present sample, micro firms form the largest cohort of those less than 10 years old (74 per cent), compared to 62 per cent of small and 42 per cent of 
Relationship Banking Within the Irish SME Sector and Its Implications

TABLE 8: IMPACT OF BANK CONCENTRATION ACROSS THE OVERDRAFT INTEREST RATE

\begin{tabular}{|c|c|c|c|c|c|c|}
\hline $\begin{array}{l}\text { Overdraft } \\
\text { Interest } \\
\text { Rate }\end{array}$ & $\begin{array}{l}\text { One } \\
\text { Bank }\end{array}$ & $\begin{array}{c}\text { Multiple } \\
\text { Banks }\end{array}$ & $\begin{array}{l}\text { Principal } \\
\text { Lender is } \\
\text { Main Bank } \\
\%\end{array}$ & $\begin{array}{l}\text { Principal } \\
\text { Lender is } \\
\text { Not Main } \\
\text { Bank } \\
\%\end{array}$ & $\begin{array}{c}\text { Proportion } \\
\text { Borrowed } \\
\text { from Main } \\
\text { Lender }>\mathbf{8 0 \%} \\
\%\end{array}$ & $\begin{array}{c}\text { Proportion } \\
\text { Borrowed } \\
\text { from Main } \\
\text { Lender <80\% } \\
\%\end{array}$ \\
\hline 4-5.9\% & 22.6 & 30.2 & 27.1 & 33.3 & 25 & 34.5 \\
\hline $6-7.9 \%$ & 16.1 & 28.3 & 24.3 & 25.0 & 21.2 & 31.0 \\
\hline 8-9.9\% & 54.8 & 30.2 & 38.6 & 33.3 & 44.2 & 24.1 \\
\hline $10-1 \mid .9 \%$ & 6.5 & II.3 & 10.0 & 8.4 & 9.6 & 10.4 \\
\hline I2-13.9\% & 0.0 & 0.0 & 0.0 & 0.0 & 0.0 & 0.0 \\
\hline Total & 100 & 100 & 100 & 100 & 100 & 100 \\
\hline
\end{tabular}

TABLE 9: IMPACT OF FIRM CHARACTERISTICS AND OVERDRAFT VOLUME ACROSS THE OVERDRAFT INTEREST RATE

\begin{tabular}{|c|c|c|c|c|c|c|c|}
\hline $\begin{array}{l}\text { Overdraft } \\
\text { Interest } \\
\text { Rate }\end{array}$ & $\begin{array}{c}\text { Micro } \\
\text { Firms } \\
\%\end{array}$ & $\begin{array}{c}\text { Small } \\
\text { Firms } \\
\%\end{array}$ & $\begin{array}{c}\text { Medium } \\
\text { Firms } \\
\%\end{array}$ & $\begin{array}{c}\text { Founded } \\
\text { Post- I } 990 \\
\%\end{array}$ & $\begin{array}{c}\text { Founded } \\
\text { Pre- I } 990 \\
\%\end{array}$ & $\begin{array}{c}\text { Overdraft } \\
<€ 50 k \\
\%\end{array}$ & $\begin{array}{c}\text { Overdraft } \\
>€ 50 k \\
\%\end{array}$ \\
\hline 4-5.9\% & 14.3 & 22.0 & 56.3 & 21.2 & 31.4 & 20.7 & 33.3 \\
\hline 6-7.9\% & 21.4 & 25.9 & 18.8 & 21.2 & 25.5 & 17.2 & 27.5 \\
\hline 8-9.9\% & 42.9 & 44.4 & 18.8 & 48.5 & 33.3 & 44.8 & 35.3 \\
\hline$|0-| 1.9 \%$ & 21.4 & 7.4 & 6.3 & 9.1 & 9.8 & 17.2 & 3.9 \\
\hline $12-13.9 \%$ & 0.0 & 0.0 & 0.0 & 0.0 & 0.0 & 0.0 & 0.0 \\
\hline
\end{tabular}

medium-sized businesses. Smaller firms are likely to have shorter banking relationships and would appear to incur higher costs as a result. Our analysis of the year of formation, pre- and post-1990 (1990 being the most popular year of business formation of respondents) reveals that the older firms incur lower interest rates but the difference is not statistically significant. This is tabulated in Table 9, along with the variation in interest rates across loan size (where considerable variation is shown to exist).

A negative relationship is depicted in Table 9 between the size of the overdraft and interest charges, as approximately 17 per cent of overdrafts of less than $€ 50,000$ incur rates of 10-11.9 per cent, in contrast to just 4 per cent of overdrafts greater than $€ 50,000$ pay rates. The difference is shown to be statistically significant at the 10 per cent level $\left(\chi^{2}=6.022, d f=3, p=0.109\right)$.

The final test for the presence of variation in interest rates is across the nature of the banking relationship. This is shown in Table 10. Whilst those in the participative cluster are deemed to pay lower interest rates on their overdrafts, the difference with the non-participative cluster is statistically insignificant. However, 
O’ Donohoe, Hanley \& Lyons

FIGURE I: DISTRIBUTION OF OVERDRAFT INTEREST MARGINS FOR FIRMS BY SIZE CLASS

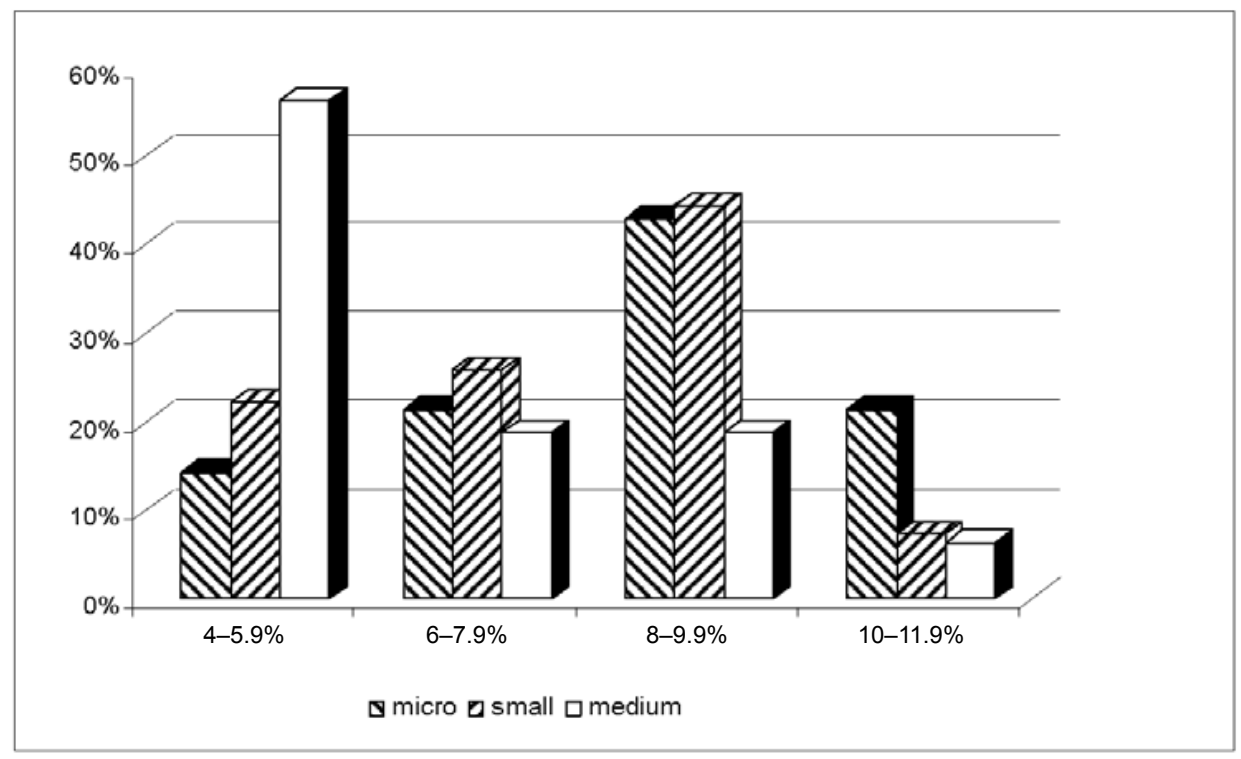

Note: $\chi^{2}$ value for this relationship is $11.225, d f=6, p=0.1$

TABLE I0: PERCENTAGE OF FIRMS ACCORDING TO INTEREST RATE ACROSS PARTICIPATIVE CLUSTERS

\begin{tabular}{lccc}
\hline $\begin{array}{l}\text { Overdraft Interest } \\
\text { Rate }\end{array}$ & $\begin{array}{c}\text { Participative } \\
\%\end{array}$ & $\begin{array}{c}\text { Non-Participative } \\
\%\end{array}$ & $\begin{array}{c}\text { Total } \\
\%\end{array}$ \\
\hline $\mathbf{4 - 5 . 9} \%$ & 29.3 & 23.5 & 28.0 \\
$\mathbf{6 - 7 . 9} \%$ & 27.7 & 11.8 & 24.4 \\
$\mathbf{8 - 9 . 9} \%$ & 35.4 & 47.1 & 37.8 \\
I0-11.9\% & 7.7 & 17.6 & 9.8 \\
I2-13.9\% & 0.0 & 0.0 & 0.0 \\
Total & 100 & 100 & 100 \\
\hline
\end{tabular}

it does suggest that there are benefits from being classed as participative in terms of information exchange with the bank and willingness to discuss problems.

\section{ANALYSIS OF THE FINDINGS}

The average duration of lender relationships in this study is comparable with the studies set in bank-dominated economies where relationship-based financing is deemed to play a significant role. An overview of the results is tabulated in Table 11. In particular, the results of this study are similar to those found by 
TABLE I I: COMPARISON OF FINDINGS AND PRIOR RESEARCH

\begin{tabular}{|c|c|c|}
\hline & Prior Research & $\begin{array}{c}\text { The Present Research on } \\
\text { Irish SMEs }\end{array}$ \\
\hline Duration (length) & $\begin{array}{l}\text { Elsas and Krahnen (I998); } \\
\text { Germany; I8.2 average; } \\
\text { I5 yrs median } \\
\text { Harhoff and Körting (1998); } \\
\text { Germany; I } 2 \text { yrs average } \\
\text { Petersen and Rajan (I994); } \\
\text { US; II yrs average } \\
\text { Cole (I998); US; } 7 \text { yrs average }\end{array}$ & $\begin{array}{l}\text { Duration average } 18.4 \text { yrs; } \\
\text { median } 15 \text { yrs }\end{array}$ \\
\hline Scope & $\begin{array}{l}\text { Ongena and Smith (2000); cross- } \\
\text { country, average number of } \\
\text { products sourced by Irish } \\
\text { firms }=3.2\end{array}$ & $\begin{array}{l}\text { Average number of products } \\
\text { sourced }=2.6\end{array}$ \\
\hline Concentration & $\begin{array}{l}\text { Harhoff and Körting ( } 1998) ; \\
\text { Germany; borrowing from } \\
\text { I.8I banks on average } \\
\text { Petersen and Rajan (I994); US; } \\
\text { borrowing from } 2.8 \text { banks on } \\
\text { average } \\
\text { Angelini et al. (I998); Italy; less } \\
\text { liquidity constraints in more } \\
\text { concentrated banking } \\
\text { relationships }\end{array}$ & $\begin{array}{l}\text { Borrowing from I.46 banks } \\
\text { on average }\end{array}$ \\
\hline Participation & $\begin{array}{l}\text { Ennew and Binks (1996); Lower } \\
\text { interest rates found for } \\
\text { participative firms }\end{array}$ & $\begin{array}{l}\text { Interest rates not found to } \\
\text { vary between participative } \\
\text { and non-participative firms }\end{array}$ \\
\hline
\end{tabular}

Harhoff and Körting (1998): their average relationship duration is 12 years, which compares to a median relationship length of 15 years in this study. ${ }^{3}$ Analogously, Elsas and Krahnen's (1998) average (median) of 18.2 (15) years duration is relatively close to the average duration of 18.4 (15) years for firms in this study. Moreover, the average length of banking relationship in this study differs from empirical work set in market-based financial systems. This includes the seminal work of Petersen and Rajan (1994) and, more recently, Cole (1998).

The number of banks used by firms is also an indicator of relationship intensity. The average number of products/services sourced by respondents from banks is 2.6, lower than the 3.2 shown by Ongena and Smith (2000) for Irish firms. However, the latter studied larger Irish firms and the difference between the two findings suggests that the smaller Irish SMEs captured in this study foster closer and more exclusive banking relationships.

Our findings on multiple-lender relationships reveal that firms have, on average, 1.46 borrowing relationships, suggesting more exclusive ties than even in the German context, where exclusive ties are a feature of the banking system. Harhoff and Körting (1998) found that German SMEs maintain relatively more exclusive 
O’ Donohoe, Hanley \& Lyons

borrowing relationships, where German firms borrow on average from 1.81 banks. Interestingly, while the mode of borrowing relationships found in this study is the same as that found by Petersen and Rajan (1994), the median is higher for Petersen and Rajan (1994), again suggesting that the firms in this study maintain relatively exclusive relationships compared to the US firms examined in the former study.

A comparison of our study on the extent to which SMEs facilitate lenders in reducing information asymmetries (extent of borrower 'participation') reveals that, unlike in the UK study by Ennew and Binks (1996), the difference in the interest paid between participative and non-participative firms in our study is insignificant. However, a greater proportion of the participative firms are seen to pay the lower rates of interest whereas the majority of the non-participative pay rates of 8 per cent or higher. There appears to be no significant relationship between the number of banks and whether security has to be provided. However, more firms with an exclusive bank relationship do not have to commit personal or business assets. The findings in this study suggest, albeit tentatively, that the more exclusive the relationship, the more likely a firm will be able to access finance. This is in line with the aforementioned Italian results from Angelini et al. (1998), who found evidence that liquidity constraints occur less frequently among firms borrowing from a limited number of banks.

\section{CONCLUSION AND LIMITATIONS}

We can conclude that from the two critical dimensions of the relationship banking definition of Boot (2000) - proprietary information and multiple interactions - that there is a high level of interaction between SMEs and account/relationship/branch managers, underpinning the importance of relationship banking in both regions. In terms of relationship characteristics, firms, on average, deal with more than one bank, and this is especially so for those in the south-east sample. Banks gather information on small firms primarily as part of their ongoing monitoring process (79 per cent) and this information plays an important role in both establishing and maintaining the banking relationship. Despite the market being heavily concentrated (two banks account for 80 per cent of SMEs' banking), a strong degree of satisfaction is manifested by small businesses surveyed, with 80 per cent citing they have not changed or are not considering changing banks. With up to 70 per cent of firms demonstrating participative behaviour, one can conclude that relationship banking is indeed a feature of the two regions assessed. Compared to their international peers, Irish firms surveyed exhibited exclusive lender-borrower relationships, a pattern more reminiscent of German SMEs. We recall that the German banking system is distinctive in its emphasis placed on close banking ties. This is an interesting finding because it either suggests a lack of choice in Ireland (possibly not the case given the high satisfaction ratings elicited by respondents) or, more likely, a genuine tendency towards close lender-borrower ties.

Regarding the cost of finance, it is unclear whether the smallest firms in our sample are charged actuarially fair rates on their overdraft borrowings, given 
their potentially higher risk profile. What is clear is the fact that they pay more for their overdraft borrowings.

One major drawback in any study of business-bank relationships is the issue of 'censoring' (Ongena and Smith, 2001). This study surveys the SMEs about their existing bank relationship but is unable to provide information about when the relationship will end. Thus, the duration of the firm-bank relationship is 'rightcensored', since the maximum length of the relationship is limited by the survey year. Furthermore, the firms surveyed may be all at different stages in their life cycle, which could potentially influence their relationship with their bank(s), and this is not captured in the current study. The second limitation is that the study focuses on borrower responses only and therefore does not capture the banks' view on relationship banking. Specifically, it was not possible to assess whether the bank evaluates the profitability of their investment in information gathering.

This is a first illustration of how significant patterns can be seen across several dimensions of the lender-business relationship. These dimensions include the duration of lender-business relationships and the cost of finance. Our unique data of Irish businesses relates to the year 2005. Ideally, we would have collected data for a larger sample of firms, which would allow us to apply standard regression techniques to control for risk factors (age and length of relationship) while simultaneously controlling for firm size and/or industry. Furthermore, this study provides no insight into the challenges in sourcing finance for Irish SMEs as identified in the Forfás Report of the Small Business Forum (2006) or the competitiveness within the Irish banking market for small firms. We leave these questions for future research.

\section{NOTES}

1 This evidence conflicts with the aforementioned studies, which conclude that exclusive business-bank relationships translate into cheaper borrowing costs. Hanley, Ennew and Binks (2006) find that UK lenders with the largest market share in SME finance over the eight years surveyed charged significantly higher interest premia to their business borrowers. This study finds evidence that lenders can abuse their market power.

2 From the open-ended question following on from the Likert rating.

3 We, like Harhoff and Körting (1998), use the median as a measure of the average value. The median is reasonably robust to outliers, unlike the mean (average).

APPENDIX I

\begin{tabular}{l} 
Survey Instrument Section A: Relationship with Banks \\
\hline QI. How often do you visit your bank branch? \\
Daily $\square \quad$ Weekly $\square \quad$ Biweekly $\square \quad$ Monthly $\square \quad$ Bimonthly $\square \quad$ Every quarter $\square$
\end{tabular}

Q2. What is the distance between your local bank branch and your business?

(Approx. number of miles) 
O’ Donohoe, Hanley \& Lyons

Q3. Does your bank offer a relationship management service? Yes $\square \quad$ No $\square$ Don't know $\square$

Q4. Have you been assigned an account/relationship manager? Yes $\square$ No $\square$

Q5. How often do you meet with your account/relationship manager?

Not applicable $\square \quad$ Monthly $\square \quad$ Bimonthly $\square \quad$ Every quarter $\square$

Other (please specify)

Q6. How often do you supply information about the business to your bank?

Monthly $\square \quad$ Bimonthly $\square \quad$ Every quarter $\square \quad$ Other (please specify)

Q7. Please specify how you would classify this communication.

You may $\checkmark$ more than one option

As a condition of financing $\square \quad$ As part of an ongoing relationship

Other (please specify) $\square$

Q8. Does your business avail of banking services via the: Internet $\square \quad$ Telephone $\square$

If not, please state why:

Q9. If your business banks via the internet and/or telephone has this resulted, in your opinion, in fewer visits to your branch?

Q10. Upon opening the bank account for your business at what stage did your company seek the first loan from the bank?

Please $\checkmark$ only one option

Once the first account was opened $\square \quad$ Within 6 months of opening the account

Within 12 months of opening the account $\square \quad$ At a later stage $\square$

QII. What information did the bank require from your business at each of the following stages? You may $\checkmark$ more than one option for each stage

Detailed business plan When first opening the first loan was

When additional As part of the Projected cash flows

Product/service details

Sales projections

Owner's investment in the firm

Management team profile

Break-even figures

Projected profit and

loss

End of year profit and loss

Projected balance sheet

End of year balance sheet

Sensitivity analysis

ongoing

account sought were sought relationship


Relationship Banking Within the Irish SME Sector and Its Implications

R\&D investment details

Detailed financial ratios

Number of employees

Other (please specify)

QI2. For each of the following statements, please circle the appropriate number which represents the extent to which you agree/disagree with it.

The bank acquires information regarding my business and uses it:

To cater for the changing needs of the firm

As part of the bank's ongoing monitoring of the firm

To improve its understanding of the nature of my business

To enhance the bank's trust in the firm

To tailor product offerings to my business's needs

To gain more power over the business

To enhance relations with the firm's management

To improve the bank's financial advice to my business

Primarily as a mechanism to sell

Strongly
disagree
I

Disagree

Neutral Agree

Strongly

agree more products and services

Any other reasons:

QI3. In your opinion do you believe that information you communicate to your bank remains private between you and the bank?

Yes $\square$

No $\square$

Q14. Would you describe the current relationship between your business and the bank as:
A close working relationship
At arms length
Other (please specify)

Q15. With regards to your business's relationship with the bank please indicate to what extent you agree/disagree with the following statements.

Please circle the appropriate number in each row

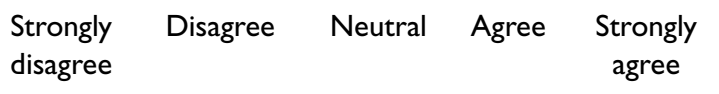

It is important to provide the

3

4

5

bank with regular and timely information

Time spent meeting with bank

2

personnel is beneficial

It is important to inform the bank if the I business faces potential difficulties

$\begin{array}{lll}3 & 4 & 5 \\ 3 & 4 & 5\end{array}$


O’ Donohoe, Hanley \& Lyons

\begin{tabular}{|c|c|c|c|c|}
\hline $\begin{array}{l}\text { Relationship banking has had a positive } \\
\text { impact on the firm's development }\end{array}$ & I & 2 & 3 & 4 \\
\hline $\begin{array}{l}\text { You prefer to avoid any contact } \\
\text { with the bank or bank manager }\end{array}$ & I & 2 & 3 & 4 \\
\hline $\begin{array}{l}\text { Relationship banking is used to } \\
\text { prevent the firm from } \\
\text { switching banks }\end{array}$ & I & 2 & 3 & 4 \\
\hline $\begin{array}{l}\text { It is important to discuss excess } \\
\text { borrowings with the bank }\end{array}$ & I & 2 & 3 & 4 \\
\hline $\begin{array}{l}\text { Banks are vital in the life of } \\
\text { small businesses }\end{array}$ & I & 2 & 3 & 4 \\
\hline $\begin{array}{l}\text { Excess time is spent meeting } \\
\text { with and providing information } \\
\text { to the bank }\end{array}$ & I & 2 & 3 & 4 \\
\hline $\begin{array}{l}\text { Banks recognise the importance } \\
\text { of their small business clientele }\end{array}$ & I & 2 & 3 & 4 \\
\hline $\begin{array}{l}\text { Time spent meeting with and } \\
\text { providing information to the } \\
\text { bank helps reduce errors }\end{array}$ & I & 2 & 3 & 4 \\
\hline $\begin{array}{l}\text { It is important to seek the } \\
\text { advice of the bank at a time } \\
\text { of financial distress }\end{array}$ & I & 2 & 3 & 4 \\
\hline
\end{tabular}

Q16. In your opinion, does your bank actively seek to retain your custom? $\quad$ Yes $\square$ No $\square$

Q17. For each of the following statements, please circle the appropriate number, which represents the extent to which you agree/disagree with it.

The nature of the relationship

$\begin{array}{ccccc}\begin{array}{c}\text { Strongly } \\ \text { disagree }\end{array} & \text { Disagree } & \text { Neutral } & \begin{array}{c}\text { Agree } \\ \text { Strongly } \\ \text { agree }\end{array} \\ \text { I } & 2 & 3 & 4 & 5 \\ \text { I } & 2 & 3 & 4 & 5 \\ \text { I } & 2 & 3 & 4 & 5 \\ \text { I } & 2 & 3 & 4 & 5 \\ \text { I } & 2 & 3 & 4 & 5 \\ \text { I } & 2 & 3 & 4 & 5 \\ \text { I } & 2 & 3 & 4 & 5\end{array}$
its bank has changed

Decision-making by the bank is now more centralised at headquarters

There has been significant change in the SME banking market

The firm's relationship with the bank has improved recently

Change in my firm's banking relations stems from the business environment

The bank's personnel change frequently and this affects bank-firm relations

The bank's emphasis has shifted towards more profit making

The firm's relationship with the bank has deteriorated recently 
Relationship Banking Within the Irish SME Sector and Its Implications

Q18. Which of the following statements best describes your business?

Please $\checkmark$ one box only

You have changed banks in the last three years

You are currently considering changing banks

You have changed banks and are considering changing again

(please skip to Q20)

You have not changed banks and are not currently considering it

(please skip to Q20)

Q19. If you have changed bank in the past three years or are thinking about it, what was/is the reason for this?

You may $\checkmark$ more than one option:

Loan application rejected

Need for increased credit

Bank mistakes

High interest rates charged

High bank charges

Approached by another bank

Poor overall relationship with the bank

Lack of transparency over fees/charges

Bank had too much control over the firm

Lack of support for business development

Other (please specify)

Q20. If you have not changed banks in the past three years nor are you thinking about changing, please indicate to what extent you agree/disagree with the following statements.

Please circle the appropriate number in each row

There is little/no difference in Strongly
disagree

Disagree Neutral Agree Strongly disagree service and products provided

agree across banks

Our business is satisfied with its current bank

Switching banks would require too much effort

Our company feels tied to its current bank

The time and money invested in the relationship makes it difficult to move banks

Due to the nature of my firm it cannot convey its creditworthiness to other banks

It is difficult to obtain suitable information to adequately compare banking services

There is a lack of competition among the banks

$\begin{array}{lllll}\text { I } & 2 & 3 & 4 & 5 \\ \text { I } & 2 & 3 & 4 & 5 \\ \text { I } & 2 & 3 & 4 & 5 \\ \text { I } & 2 & 3 & 4 & 5 \\ 1 & 2 & 3 & 4 & 5 \\ \text { I } & 2 & 3 & 4 & 5 \\ & 2 & 3 & 4 & 5\end{array}$


O’ Donohoe, Hanley \& Lyons

$\begin{aligned} & \text { Relationship formed with } \\ & \text { current bank results in benefits }\end{aligned}$
that outweigh the costs

Q21. How does your business assess the pricing of the financial services it acquires? Please $\checkmark$ only one option

Based on the cost of each service sought $\square$

Based on cost of the total bundle of services sought

Q22. Does your business seek advice from the bank when it is making critical business decisions? Yes $\square \quad$ No $\square$

If yes, please specify why your business seeks the bank's advice for critical decision making?

\section{Section B: Bank Financing and Firm Characteristics}

QI. What year did your firm begin trading?

Q2. How many people does your company currently employ? Full-time Part-time

Q3. What has been your average rate of growth in company sales over the last three years? Please $\checkmark$ one box only
Under $1 \%$
$1-5 \%$
$6-10 \%$
$1 \mathrm{I}-20 \%$
$21-49 \%$
$50-99 \%$
Over $100 \%$

Q5. How many banks do you borrow from?

Q6. Is your principal lender also your main bank? Yes $\square \quad$ No $\square$ Don't have a main bank $\square$ (Main Bank - Your business deals with this bank and it accounts for $80 \%$ or more of your financial transactions)

Q7. Approximately what percentage of your business's borrowings is sourced from your principal lender?

0-19\% $\square \quad 20-39 \% \square \quad 40-59 \% \square \quad 60-79 \% \square \quad \square \quad$ more than $80 \%$

Q8. Please rate the usage of each of the following sources of finance sourced from your principal lender over the last three years. In doing so we ask that you identify the year in which it was secured, the year of final repayment and to circle the importance of each source.

\begin{tabular}{|c|c|c|c|c|c|c|c|}
\hline & $\begin{array}{c}\text { Year } \\
\text { secured }\end{array}$ & $\begin{array}{l}\text { Year of final } \\
\text { repayment }\end{array}$ & $\begin{array}{c}\text { Not } \\
\text { important }\end{array}$ & $\begin{array}{c}\text { Of little } \\
\text { importance }\end{array}$ & $\begin{array}{l}\text { Moderately } \\
\text { Important }\end{array}$ & Important & $\begin{array}{c}\text { Very } \\
\text { Important }\end{array}$ \\
\hline $\begin{array}{l}\text { Bank loan } \\
<5 \text { years }\end{array}$ & & & I & 2 & 3 & 4 & 5 \\
\hline $\begin{array}{l}\text { Bank loan } \\
>5 \text { years }\end{array}$ & 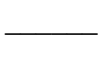 & 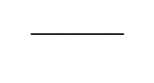 & I & 2 & 3 & 4 & 5 \\
\hline $\begin{array}{l}\text { Working } \\
\text { capital } \\
\text { finance }\end{array}$ & 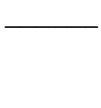 & 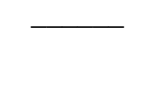 & 1 & 2 & 3 & 4 & 5 \\
\hline
\end{tabular}


Relationship Banking Within the Irish SME Sector and Its Implications

\begin{tabular}{|c|c|c|c|c|}
\hline $\begin{array}{l}\text { Business } \\
\text { overdraft }\end{array}$ & I & 2 & 3 & 4 \\
\hline $\begin{array}{r}\text { Commercial } \\
\text { mortgages }\end{array}$ & I & 2 & 3 & 4 \\
\hline $\begin{array}{l}\text { Hire } \\
\text { purchase }\end{array}$ & I & 2 & 3 & 4 \\
\hline $\begin{array}{l}\text { Invoice } \\
\quad \text { discounting }\end{array}$ & I & 2 & 3 & 4 \\
\hline $\begin{array}{l}\text { Supplier } \\
\text { finance }\end{array}$ & I & 2 & 3 & 4 \\
\hline $\begin{array}{l}\text { Business } \\
\text { credit cards }\end{array}$ & I & 2 & 3 & 4 \\
\hline $\begin{array}{l}\text { Other } \\
\text { (please } \\
\text { specify) }\end{array}$ & I & 2 & 3 & 4 \\
\hline
\end{tabular}

Q9. Please select the interest rate your business is currently charged for each of the following sources of finance by ticking the appropriate box.

\begin{tabular}{|c|c|c|c|c|}
\hline Bank loan $<5$ years: & $\begin{array}{l}4-5.9 \% \square \\
12-13.9 \% \square\end{array}$ & $6-7.9 \% \square$ & 8-9.9\% $\square$ & $10-11.9 \% \square$ \\
\hline Bank loan $>5$ years: & $\begin{array}{l}4-5.9 \% \square \\
12-13.9 \% \square\end{array}$ & $6-7.9 \% \square$ & 8-9.9\% $\square$ & $10-11.9 \% \square$ \\
\hline Leasing: & $\begin{array}{l}4-5.9 \% \square \\
12-13.9 \% \square\end{array}$ & $6-7.9 \% \square$ & 8-9.9\% $\square$ & $10-11.9 \% \square$ \\
\hline Hire purchase: & $\begin{array}{l}4-5.9 \% \square \\
12-13.9 \% \square\end{array}$ & $6-7.9 \% \square$ & 8-9.9\% $\square$ & $10-11.9 \% \square$ \\
\hline Business overdraft: & $\begin{array}{l}4-5.9 \% \square \\
12-13.9 \% \square\end{array}$ & $6-7.9 \% \square$ & 8-9.9\% $\square$ & $10-11.9 \% \square$ \\
\hline
\end{tabular}

Q10. Please select the credit limit that currently applies for each of the following sources of finance by ticking the appropriate box.

$\begin{array}{lll}\text { Bank loan }<5 \text { years: } & € 0-€ 9,999 \square \quad € 10,000-€ 24,999 \square & € 25,000-€ 50,000 \square \\ & \text { Greater than } € 50,000 \square \\ \text { Bank loan }>5 \text { years: } & € 0-€ 19,999 \square \quad € 20,000-€ 49,000 \square \quad € 50,000-€ 100,000 \square \\ & \text { Greater than } € 100,000 \square \\ \text { Hire purchase: } & € 0-€ 9,999 \square \quad € 10,000-€ 24,999 \square \quad € 25,000-€ 50,000 \square \\ & \text { Greater than } € 50,000 \square \\ \text { Leasing: } & € 0-€ 9,999 \square \quad € 10,000-€ 24,999 \square \quad € 25,000-€ 50,000 \square \\ & \text { Greater than } € 50,000 \square \\ \text { Business overdraft: } & € 0-€ 4,999 \square \quad € 5,000-€ 9,000 \square \quad € 10,000-€ 19,999 \square \\ & € 20,000-€ 50,000 \square \quad \text { Greater than } € 50,000 \square\end{array}$

QII. Do you believe that your business will need more finance for expansion in the future? Yes $\square \quad$ No $\square$

Q 12. Do you believe that finance for future growth is available to your business? Yes $\square \quad$ No $\square$

If no, please state why 
O’ Donohoe, Hanley \& Lyons

Q13. What would be the worst conditions your firm would be prepared to undertake in order to secure additional bank lending?

Please $\checkmark$ only one option

A higher interest rate and more collateral

The same interest rate but more collateral

A higher interest rate but the same collateral

The same interest rate and the same collateral

QI4. Please select the types of collateral required by the bank(s) as security at the following stages. You may $\checkmark$ more than one option for each stage.

$\begin{array}{cccc}\begin{array}{c}\text { When first } \\ \text { opening the }\end{array} & \begin{array}{c}\text { When the } \\ \text { first loan was } \\ \text { account }\end{array} & \begin{array}{c}\text { When additional } \\ \text { loans/services }\end{array} & \begin{array}{c}\text { As part } \\ \text { of the ongoing } \\ \text { relationship }\end{array} \\ \square & \square & \text { were sought } & \square \\ \square & \square & \square & \square \\ \square & \square & \square & \square \\ \square & \square & \square & \square\end{array}$

\section{REFERENCES}

Angelini, P., Di Salvo, R. and Ferri, G. (1998). Availability and Cost of Credit for Small Businesses: Customer Relationships and Credit Cooperatives, Journal of Banking and Finance, Vol. 22, No. 6, pp. 925-954.

Armstrong, J. and Overton, T. (1977). Estimating Nonresponse Bias in Mail Surveys, Journal of Marketing Research, Vol. 14, No. 2, pp. 396-402.

Berger, A. and Udell, G. (1995). Relationship Lending and Lines of Credit in Small Firm Finance, Journal of Business, Vol. 68, No. 3, pp. 351-381.

Berger, A. and Udell, G. (2006). A More Complete Conceptual Framework for SME Finance, Journal of Banking and Finance, Vol. 30, No. 11, pp. 2945-2966.

Blackwell, D.W. and Winters, D.B. (1997). Banking Relationships and the Effect of Monitoring on Loan Pricing, Journal of Financial Research, Vol. 20, No. 2, pp. 275-289.

Bodenhorn, H. (2003). Short-Term Loans and Long-Term Relationships: Relationship Lending in Early America, Journal of Money, Credit and Banking, Vol. 35, No. 1, pp. 485-504.

Boot, A. (2000). Relationship Banking: What Do We Know? Journal of Financial Intermediation, Vol. 9, No. 1, pp. 7-25.

Cole, R. (1998). The Importance of Relationships to the Availability of Credit, Journal of Banking and Finance, Vol. 22, Nos. 6-8, pp. 959-977.

Cole, R., Goldberg, L. and White, L. (2004). Cookie-Cutter versus Character: The Microstructure of Small Business Lending by Large and Small Banks, Journal of Financial and Quantitative Analysis, Vol. 39, No. 2, pp. 227-251.

Coleman, S. (2000). Access to Capital and Terms of Credit: A Comparison of Men- and Women-Owned Small Businesses, Journal of Small Business Management, Vol. 38, No. 1, pp. 37-53.

Degryse, H. and Van Cayseele, P. (2000). Relationship Lending Within a Bank-Based System: Evidence from European Small Business Data, Journal of Financial Intermediation, Vol. 9, No. 1, pp. 90-109.

Diamond, D. (1991). Monitoring and Reputation: The Choice Between Bank Loans and Directly Placed Debt, Journal of Political Economy, Vol. 99, No. 4, pp. 689-721. 
Dun and Bradstreet (2001). Companies in Ireland, Dun and Bradstreet, <http://www. dandb.com> [accessed 19 February 2009].

Elsas, R. (2005). Empirical Determinants of Relationship Lending, Journal of Financial Intermediation, Vol. 14, No. 1, pp. 32-57.

Elsas, R. and Krahnen, J. (1998). Is Relationship Lending Special? Evidence from Credit-File Data in Germany, Journal of Banking and Finance, Vol. 22, Nos. 10-11, pp. 1283-1316.

Elyasiani, E. and Goldberg, L. (2004). Relationship Lending: A Survey of the Literature, Journal of Economics and Business, Vol. 56, No. 4, pp. 315-330.

Ennew, C. and Binks, M. (1996). Good and Bad Customers: The Benefits of Participating in the Banking Relationship, International Journal of Bank Marketing, Vol. 14, No. 1, pp. 5-13.

Ennew, C. and Binks, M. (1998). Smaller Businesses and Relationship Banking: The Impact of Participative Behaviour, Entrepreneurship, Theory and Practice, Vol. 21, No. 1, pp. 83-92.

Forfás (2006). Small Business is Big Business: Report of the Small Business Forum, Dublin: Department of Enterprise, Trade and Employment.

Hanley, A., Ennew, C. and Binks, M. (2006). The Price of UK Commercial Credit Lines: A Research Note, Journal of Business Finance and Accounting, Vol. 33, No. 5, pp. 932-938.

Harhoff, D. and Körting, T. (1998). Lending Relationships in Germany: Empirical Evidence from Survey Data, Journal of Banking and Finance, Vol. 22, No. 10, pp. 1317-1353.

Hernandez-Canavas, G. and Martinez-Solano, P. (2006). Banking Relationships: Effects on Debt Terms for Small Spanish Firms, Journal of Small Business Management, Vol. 44, No. 3, pp. 315-333.

Horiuchi, T., Packer, F. and Fukuda, S. (1988). What Role Has the 'Main Bank' Played in Japan?, Journal of Japanese and International Economies, Vol. 2, No. 1, pp. 159-180.

Lehmann, E. and Neuberger, D. (2001). Do Lending Relationships Matter? Evidence from Bank Survey Data in Germany, Journal of Economic Behaviour and Organization, Vol. 45, No. 4, pp. 339-359.

Ongena, S. and Smith, D. (2000). What Determines the Number of Bank Relationships? Cross-Country Evidence, Journal of Financial Intermediation, Vol. 9, No. 1, pp. 26-56.

Ongena, S. and Smith, D. (2001). The Duration of Bank Relationships, Journal of Financial Economics, Vol. 61, No. 3, pp. 449-475.

Peltoniemi, J.J. (2007). The Benefits of Relationship Banking: Evidence from Small Business Financing in Finland, Journal of Financial Services Review, Vol. 31, No. 1, pp. 153-171.

Petersen, M. and Rajan, R. (1994). The Benefits of Lending Relationships: Evidence from Small Business Data, Journal of Finance, Vol. 49, No. 3, pp. 1367-1400.

Petersen, M. and Rajan, R. (1995). The Effect of Credit Market Competition on Lending Relationships, Quarterly Journal of Economics, Vol. 110, No. 2, pp. 406-443.

Sjögren, H. (1994). Long-Term Financial Contracts in the Bank-Orientated Financial Systems, Scandinavian Journal of Management, Vol. 10, No. 2, pp. 315-330.

Stein, J.C. (2002). Information Production and Capital Allocation: Decentralised versus Hierarchical Firms, Journal of Finance, Vol. 57, No. 5, pp. 1891-1921.

Udell, G.F. (2008). What's in a Relationship? The Case of Commercial Lending, Business Horizons, Vol. 51, No. 1, pp. 93-103. 